\title{
Meervoudige denke: Versmoor/vermoor instellings denke?
}

\author{
CS DE BEER*
}

\section{Opsomming:}

Denke is die mees uitsonderlike vermoë van mense. Vir mense om volwaardige mense te wees, is die volle ontwikkeling van hierdie vermoë noodsaaklik. Wanneer dit afgeskeep word, word mense tot minder as mense en alle verhoudinge waarby mense betrokke is ly op een of ander wyse skade. Hierdie skade kan mettertyd katastrofiese afmetings aanneem. Dit kan samelewings in duie laat stort; dit kan selfs die ondergang van beskawings beteken.

Hierdie artikel besin oor die belangrikheid van meervoudige of komposisionele denke, as die ideale denkvorm, oor die wesenlike probleem dat denkontwikkeling verhinder word omdat daar eerder op enkelvoudige denke, as maklik aanleerbare denkvorm, klem gelê word en oor die moontlike armoedige gevolge hiervan vir indiwidue en samelewings van sodanige strategieë, soos dit veral in institusionele verbande tot uitdrukking kom, verwesenlik word, selfs afgedwing word: onderwys, politiek, kultuur. Die versmoring/vermoording van denke word ' $\mathrm{n}$ werklikheid. Uiteindelik word enkelvoudige denke die houding van die hele samelewing.

Die ernstige afmetinge wat die verlies aan deeglike denke reeds aangeneem het, is van groot omvang. Dit raak skole, universiteite, wetenskapwerk, politieke instellings, administratiewe aktiwiteite oor ' $\mathrm{n}$ breë spektrum - eintlik alreeds die hele samelewing. Hiermee word ons voor groot uitdaginge gestel. Indien hierdie oorwoë argumente geldig is, soos baie inderdaad beweer, moet die situasie ten alle koste omgekeer word. Voorstelle word in hierdie verband gemaak.

Dit is allereers nodig om die gebrekkigheid van gebrekkige denke en die gevolge daarvan te bedink. Verder moet besef word dat gesindheid en ingesteldheid ten opsigte van armoedige denke moet verander, die armoede daarvan moet aanvaar word en ook dat ander denkweë moontlik is. Terselfdertyd behoort ' $n$ besef lewendig gehou te word dat die kompleksiteit van die werklikheid, mensewerklikheid en natuurwerklikheid, groot en meervoudig in omvang is. Geen enkelvoudige, lineêre en dus reduktiewe denke, sou afdoende antwoorde op hierdie uitdagings van so ' $\mathrm{n}$ werklikheid kon verskaf nie. Slegs denke wat bereid is om die volle rykdom van die werklike te aanvaar en dienooreenkomstig aan die dink te raak, kan hoop op sinverwesenliking en mens-en werklikheidsverryking bewerkstellig.

Trefwoorde: lineêre denke; protesterende denke; meervoudige denke; komposisionele denke; meervoudige werklikheid.

Dissipline: Interdissipline 


\section{Abstract}

\section{Multiple thinking: do institutions smother/kill thought?}

Thought is the most distinct ability of humans. For humans to be fully developed beings the full development of this ability is required. When this is neglected humans become less human and all relationships humans are involved with will be damaged. This damage can with time assume catastrophic proportions. It can cause the collapse of societies and even the downfall of civilisations.

This article reflects on the importance of multiple or compositional thinking as the ideal mode of thinking, on the essential problem that thought development is hindered by the preferable emphasis on simplified thinking, as the easily adoptable mode of thinking, and on the possible impoverishing consequences for individuals and societies of such strategies as it finds expression, comes to fruition and are enforced in institutional contexts: education, politics, culture. The smothering/killing of multiple thinking takes effect. Eventually simplified thinking becomes the general attitude in society as a whole.

The alarming proportions already assumed due to the loss of thorough thinking are immense. It affects schools, universities, scientific work, political institutions, and administrative activities over a broad spectrum - as a matter of fact already the whole of society. We are confronted hereby with enormous challenges. In case these considered arguments are valid, as many would suggest, the situation has urgently to be reversed. Some proposals in this regard are made.

It is first of all required to ponder the limitations of limited thought and its consequences. Additional to this it is necessary to realise that attitudes regarding poor thinking should be changed, that the poverty thereof be accepted, and that alternative thought routes are available. At the same time an awareness of the complexity of reality, human reality as well as natural reality, in its multiplicity and scope, should be kept vividly alive. No simplified, linear, and hence reductive thinking can offer adequate answers to the challenges of such a reality. Only a thought, willing to accept this and to think accordingly, will have a hope of the fulfilment of meaning and the enrichment of humans and reality.

Keywords: linear thinking; protest thinking; multiple thinking; compositional thinking; multiple reality.

Discipline: Interdiscipline

\section{Inleiding}

Die leser behoort uit die tema af te lei dat menslike denke baie belangrik is. Dit mag klink na ' $n$ vanselfsprekendheid. Alle mense dink immers. Daarteen stry niemand en ' $n$ mens sal selfs verbaas wees oor hoeveel mense, selfs diegene van wie dit nie verwag word nie, wel dink. In hierdie artikel word die feit egter beklemtoon dat mense tot die maksimum behoort te dink, heelhartig moet dink, so goed as moontlik behoort te dink (Pascal). Enersyds het dit met selfverwesenliking te doen, met die volle ontplooiing van die self, met die omvattendste en indringendste moontlike ingebedheid in die werklikheid, midde in dit wat is. Dit is die enigste manier hoe mense by ' $\mathrm{n}$ eie plek in hierdie geheel kan uitkom en sin daarvan kan maak. Dit gaan egter ook om die samelewing en wat van 'n samelewing sonder oortuigde denkers word - en onthou: hier word nie in die eerste plek, of selfs slegs van filosowe gepraat nie. Samelewings kan sonder professionele filosowe wees, maar gewis nie sonder denkende mense nie. Daarsonder gaan hulle onder, verloor hulle die sin van die lewe, want hulle verloor alle perspektief en veral 'n uitsig op die toekoms. 
Daarom: Om so goed moontlik te dink, is ' $\mathrm{n}$ soort roeping wat met menswees gegee is, in ons menswees ingebou is. Hoe meer en beter daar gedink word, hoe meer en beter is die soort mense wat ons word. Die strewe moet altyd bly: die ontwikkeling van volle humaniteit; dit beteken ook vervulde humaniteit. Dit is geen vanselfsprekende saak nie. Denke het baie vyande, dikwels selfs uit onverwagse oorde.

Deur die eeue het baie al gewaarsku teen die fataliteit van denk-afwesigheid. Socrates se besoeke aan die markplein in Athene, Griekeland, was om die volk aan die dink te kry, mense vrae te laat vra oor hulle doel in die lewe. Pascal (1963:116) maak die punt:

\section{Heel onze waardigheid is dus in het denken gelegen. ... Laten wij dus ons bes doen goed te denken; dat is het beginsel der moraal.}

Nietzsche spreek sy beswaardheid uit oor die feit dat skole nalaat om kinders te leer dink! Heidegger, die filosoof oor wie die meeste in die wêreld geskrywe is, merk met weemoed op dat sy pragtige boek Was heisst Denken (Wat beteken dit om te dink?) (1971) een van sy mins gelese boeke is. Jacques Lacan maak 'n groot saak uit oor "die wil tot onkunde", wat direk te doen het met ' $\mathrm{n}$ doelbewuste onwilligheid om te dink, wat byna wesenlik tot menswees behoort, ongeag die vermoë daartoe waaroor mense beskik.

On-kundigheid en denk-loosheid, is onlosmaaklik verbind, is karperde wat ons - indiwidue, groepe, samelewings, kulture, beskawings -- oor die afgronde voer. Enige studie van enige sulke entiteite bring ons telkens by hierdie gedagte uit. Dit lei mense tot domheid, onnoselheid en afstomping. Daar is in die jongste tyd nogal heelwat hieroor geskrywe: George Steiner (1999) met sy Barbarisme van onkunde, Avital Ronel (2003) met haar Stupidity en die bekende Le Magazine Littéraire (2007) met 'n spesiale uitgawe oor La bêtise (domheid) is maar drie voorbeelde. Die grootste onguns, of selfs minagting, wat aan mense bewys kan word, is om hulle die reg tot optimale denke te ontsê. Dit maak van mense minder mense, gebrekkige mense; dit is soos iemand wat sonder ' $n$ ledemaat oor die weg moet kom. Die verskil is egter: in hierdie geval is die ledemaat wel daar maar doelbewus onderontwikkel en as gevolg van die onderbenutting gaan dit natuurlik agteruit en verloor uiteindelik sy funksie. Dit maak van mense wesens wat op twee in plaas van vier silinders loop. Vitaliteit en energie is weg. Die ergste is dat hierdie aftakeling van menswees dikwels onder die voorwendsel van goeie of selfs die beste bedoelinge geskied in die naam van vaardigheidsontwikkeling en die daarmee gepaardgaande berekende bevordering van resepmatigheid.

\section{Die versmoring/vermoording van denke}

Die mate waartoe ons tot volle, denkende, reflekterende mense ontwikkel hang baie van onsself af, maar het ook baie te doen met die omgewings, samelewings, kulture waarin ons ons bevind, die kwaliteite, inspirasies en geestelike gehalte daarvan en ook van die instellings wat binne hierdie kontekste beslag kry en invloed uitoefen. Veral vier groepe instellings is hier van belang: die onderwys, navorsing, korporatiewe en politieke instellings. Die kernvraag hier is of instellings meervoudige denke versmoor/vermoor? Die hoofklem, vir ons doeleindes, sal op die onderwys as instelling val, veral hoër onderwys en veral ook die mate waartoe dit met navorsing en wetenskap verband hou. Wat my aan die dink gesit het oor hierdie spesifieke tema is veral die onlangse boek van Mary Evans: Killing thinking: the death of the universities (2004) en saam hiermee behoort die boek van Frank Furedi: Where have all the intellectuals gone? (2006) ook aandag te geniet. 
Haar gedagtes het op vrugbare grond geval, want as ' $n$ mense vir jare aan universiteite en navorsingsinstellings betrokke was en dit enigsins op 'n deurdagte wyse probeer doen het, ontdek jy gou hoe " $n$ groot vyand van volle denke hierdie sogenaamde "denk"-instellings eintlik is. Hulle werk almal onder die voorwendsel van denkbevordering in die oortreffende trap sonder dat daar besef word dat dit eintlik maar herhalende, lineêre en reproduktiewe denke is wat hulle strewe om te bevorder. Michel Serres (1997:93) skrywe byvoorbeeld:

\section{All my life I marvelled at the hatred of intelligence that makes up the tacit social contract of so-called intellectual establishments.}

Dit laat my dink aan ' $n$ ervaring van ' $n$ aantal jaar gelede toe ek vir ' $n$ navorsingsprogram van die destydse Wetenskaplike Adviesraad, wat oor die implementering en benutting van navorsingsbevindinge gehandel het, verantwoordelik was en ek voorgestel het dat ' $n$ bepaalde filosoof (Radnitzky), wat geheel en al in die kraal van hierdie mense en hulle program gepraat en geskrywe het, uitgenooi word om insette tot die program te maak. Die aansoek was onsuksesvol. Op ' $n$ dag ontvang ek ' $n$ lêer van die president van een navorsingsraad wat dokumentasie oor vergaderings wat gehou is, bevat het en ontdek toe in die lêer 'n nota (wat tydens een van die vergaderings gestuur was) van die president van 'n ander navorsingsraad met die woorde:

\section{Kan ons dit werklik bekostig om mense van dié aard by ons program betrokke te kry?}

Die verklaring vir die mislukte aansoek lê voor die hand. "Mense van dié aard" (maw. Professionele denkers, dws mense wat denke in ' $n$ omvattende sin wil bevorder) is nie bekostigbaar vir navorsingsrade nie, selfs al praat hulle in dieselfde idioom en bevorder hulle wêreldwyd dieselfde saak. "The hatred of intelligence" waaroor Serres skrywe, oorheers dikwels die besluite wat in institusies geneem word.

Ons moet ook onthou dat instellings woeker met mag en dus heul met maghebbers om hulle aan hulle kant te kry, want daar kry hulle hulle geld vandaan, behalwe die wat hulle self moet genereer, maar meesal onnadenkend doen. Maghebbers floreer natuurlik op hierdie impak wat hulle weet hulle mag het. Niemand in die magstrukture mag ooit in die verleentheid gestel word nie. Om denkende mense verleë te maak, is natuurlik eerder ' $n$ deug en selfs 'n stokperdjie, maar nooit "n skande nie. Die onlangse "waterreferaat-episode" (2008) is een baie ontstellende voorbeeld hiervan. Instellings kan eerder ' $n$ hele bevolking se besmetting bevorder, of onge-erg daaroor wees, as om toe te laat dat een denkende navorser ' $n$ patetiese regering, wat die minimum aan dienste verskaf, deur dringende en tydige waarskuwings in die verleentheid plaas. Die ergste van alles, so word deur die betrokke direkteur-generaal berig, is dat min of meer dieselfde referaat juis ' $n$ maand of wat tevore by die Departement Waterwese gelewer is met omvattende debatvoering daaroor en sonder probleme. Mag het nog altyd en sal ook altyd ware denke kortwiek, aan bande lê, versmoor en selfs vermoor. Natuurlik sal almal beweer dat denke bevorder word, maar dan ' $n$ baie duidelik verskraalde en presies gedefinieerde denke. In hierdie nuwe wêreld van geleerdheid het ons 'n nagmerrie van 'n ander aard, skrywe Evans (2004:52): "the horrors of force, violence, physical coercion and hardship are replaced by the slow suffocation of the spirit, the intellect and the capacity to resist." Soos in die Engeland waaroor sy skrywe, het ons in Suid-Afrika ook hewige porsies van alles hiervan. Mense word fisies vermoor en geestelik versmoor en vermoor. 
Om verder terug te keer na Evans. Intellektuele vitaliteit en kreatiwiteit moet plek maak vir ouditering, assessering, meting en regulering. Die verskuiwing wat hier ter sprake is, word so deur haar verwoord:

[It] is a shift from a collective world in which independent and critical thought was valued, to a collective world in which universities are expected to fulfil not these values but those of the marketplace and the economy. This discussion is not derived from a nostalgia for the past, but a fear for the future. In particular the concern which inspires these pages is that of the evolution of the universities into institutions which only serve a very smallminded master: the rational bureaucratic state of the twenty-first century. (Evans 2004:3).

In hierdie instellings is denke ' $n$ hoogs-toevallige en oorbodige verskynsel en besmet met ideëblindheid. In sulke situasies gee die berekenbare, voorspelbare en beheerbare - en veral ook die voorstelbare - die toon aan. Standaardisering in lyn met die laagste gemene deler is die doelwit al word dit internasionaal genoem. Die 'slaap van die rede' (Evans 2004:128) het finaal ingetree. Ons het ons eie katastrofiese Benghu/Asmal episodes waarvan Suid-Afrikaanse universiteite waarskynlik nooit sal herstel nie. Dit is ewe moeilik om te sien hoe die skole gaan herstel. Die gereelde reaksie oor eksamenuitslae by skole en die retoriek daaromheen bevestig weer duidelik hoe min daar werklik omgegee word vir dit waarom dit eintlik in ons samelewing behoort te gaan.

Hierdie verskuiwing geskied boonop onder die vaandel van die hoog-edele demokratiese ideaal en die nog edeler transformasieproses. Sosiale geregtigheid, volgens ' $n$ bepaalde definisie en ekonomiese noodsaaklikheid, ook volgens ' $n$ sekere begrip daarvan, is twee van die belangrikste pilare wat nuwe mense moet voortbring uit die nuwe doelgerigte, uitkomsgerigte, SAQAgesertifiseerde, leerplanne. Wat die verwikkelinge werklik meebring is ' $\mathrm{n}$ kwasie-demokratiese ethos van instemming met die waardes van die mark-ekonomie waarbinne denke onbekostigbaar geword het.

\section{Under the umbrella of the principle that recipients of public money should be accountable to public scrutiny was included an explicit commitment to a particular form of public - a public which wholeheartedly endorsed the market (Evans 2004:23).}

Vir hierdie enggeestige meester, die rasioneel-burokratiese staat "only battery farming for the mind promises that reason will never escape to serve anything except the most avaricious and limited keeper”. (Evans 2004:27).

Sy gaan egter nog verder en baie meer op die punt af wanneer sy die fokus van navorsingsinstellings ook binne universiteite karakteriseer. Sy skrywe:

But the skills necessary for technical competence are not the same as those necessary, indeed essential, for intellectual creativity or understanding. Moreover, it is a basic misunderstanding of science and technology to assume that learning in these subjects necessarily follows a mechanistic pattern. The sad truth is that the authors of assessment want the world, and indeed everything we might possibly know about it, to be organized into the bite size portions of mass catering. The standard potato chip becomes the standard idea, it has measurements and it has contours and nobody will be given one that is a peculiar shape or made of different materials. Given that mass catering also depends upon 'portion control' we can also expect that no one will receive more (or less) 'knowledge' than anyone else. (Evans 2004:71-72). 
Mag en die haat vir intelligensie seëvier hier.

Terwyl die devaluasie van die sosiale en intellektuele waarde van ' $\mathrm{n}$ graad een van die belangrike prestasies van hierdie verskuiwing is, is 'die vermorsing van menselewens' waarvan Eliot in Middelmarch skrywe (Evans 2004:40), waarskynlik die grootste, maar ook hartseerste uitkoms van uitkomsgerigte onderwys en portuurge-evalueerde navorsing. Aangesien die hele aangeleentheid van hierdie betoog handel oor die impak van instellings op indiwidue en gemeenskappe se denke en lewens, moet enige alternatief, maar veral die komposisionele denke, intens met mense en hulle maksimale vermoëns rekening hou en ook met die werklike ontmenslikende aspekte van die impak. Soos geargumenteer is: die lineêre, enkelvoudige, representatiewe denke mak van ons minder volwaardige mense wat ook afskuur op menseverhoudinge en institusionele opsette. Die mensvervullende, meervoudige of komposisionele denke moet sterk inspeel op die verwesenkliking hiervan in alle kontekste anders raak die lewens vermors. Hiervoor is die etiek van Levinas besonder waardevol en veral ook in die lig van Judith Butler se interpretasie daarvan vir institusionele opsette, veral opsette waarbinne fel aanslae teen die menswetenskappe en veral die humaniora (deesdae so algemeen) geloods word. Individuele kwaliteite, institusionele foki, samelewingsgehalte verrys uit ' $n$ etiese ingesteldheid en keer telkens daarheen terug. (Kyk Butler, 2006: 128-151). Hierby kan Pascal weer in herinnering geroep word: Om goed te dink is die beginsel van die moraal.

Michèle Lamont (2009) bevestig in haar onlangse studie, wat onder die titel How professors think: inside the curious world of academic judgment gepubliseer is, tot watter mate die algemeen aanvaarde navorsingsprosesse akademici dwing om in die rigting van eenduidige, lineêre denke te dink teenoor en ten koste van meervoudige denke. Die hele oefening van portuurevaluasie is, al is dit onbedoeld, gemik op die versmoring van denke. Dit is 'n samevoeging van navorsingsmatige, bestuursmatige en ekonomiese magte om navorsers te manipuleer en veral om navorsers deur ander misbruikte navorsers gemanipuleer te kry om op sekere maniere te dink. Die oefening is verder grootliks gebaseer op empiristiese en positivistiese strategieë van meting, berekening en kontrole. Die bibliometriese meting van aangehaalde werke, as een voorbeeld van baie, gee ' $n$ indruk of skep ' $n$ vermoede van impak en kwaliteit, maar laat net te veel buite rekening om hoegenaamd werklike geldigheid te geniet. Studente het wel die aandag daarop gevestig dat daar gelukkig enkele dosente, navorsingsbestuurders en redakteurs is wat wel deur hul gewetes en met geïnspireerde geestelike verantwoordelikheid, dikwels onder moeilike omstandighede van institusionele beperkinge, wonderlike werk verrig in terme van meervoudige denke.

Dit is teen hierdie agtergrond dat die pas vrygesteld boek van Gumede en Dikeni (2009) oor 'die armoede aan idees' in die kol is en die outeurs deelnemers is aan die oproep tot protesdenke. Die politieke implikasies van verskraalde denke het verreikende gevolge wat moeilik in situasies van denkloosheid raakgesien word. Die armoede aan idees het alles te doen met hoe daar gedink word of nie gedink word nie. Die grootste enkele oorsaak van ideë-armoede is denkarmoede. Tensy daar dringend op ' $n$ omvattende en indringende skaal werk gemaak word van meervoudige denke, soos wat hier voorgestel word, kan ons in ons land slegs afwaarts en agteruit beweeg soos wat tans al sterker die geval is en duidelik in hierdie publikasie aangetoon word. Die huidige situasie vra vir protes.

\section{Protesterende denke}

Hierteenoor behoort ons baie sterker stelling in te neem as om in teekamergesprekke ons onvergenoegdheid uit te spreek. Ons is meesal so verward en verdwaasd oor die taktieke, 
strategieë en politiekerye waartoe instellings in staat is dat ons nie eintlik weet wat om te sê nie. Boonop is dit nie politiek korrek om iets te sê nie. Mag, politiek en strategie neutraliseer ons. Tog moet ons weet dat ons ' $\mathrm{n}$ saak het. Die kosbaarste en mees unieke van ons menswees, waarsonder ons nie in die volwaardige sin mense is, of kan wees nie, is op die spel: ons denkvernuf. Op grond van ' $n$ oortuigde entoesiasme moet daar luid aangekondig en geprotesteer word oor " $n$ paar kernsake. In haar skerp ontleding van die gees van ons tyd as " $n$ tyd van katastrofes" beklemtoon Isabelle Stengers (2009) die belangrikheid daarvan om weerstand te bied "teen die barbaarsheid wat aan die kom is". Die protes teen enkelvoudige denke van hierdie artikel geskied in volle vereenselwiging met Stengers se oproep.

1 Die grense van die akademie strek veel wyer en verder as die ekonomie en die mark en is dus werd om verdedig te word, veral in die lig van die neweverskynsels van so ' $n$ eenvoudige fokus soos tot hiertoe beklemtoon is. Wat kan verdedig word van die akademiese instellings?
[T]hey constitute a set of standards and aspirations that are democratically available and can generally inform the social world about the possibilities of the intellect. Going to university to learn how to process received, bowdlerized knowledge ... is not about learning to think or consider. It is about learning how to organize pre-packaged information. (Evans 2004:44).

Dit is en bly volledig onvoldoende.

2 Verder, idees moet oorweeg word, nie alleen vir sover hulle veranderinge in die wêreld bewerkstellig nie, maar veral in terme van die verskil wat idees aan ander idees maak. Die verhouding tussen idees, die waardering en evaluasie van idees, die woeker daarmee, die besef waartoe Edgar Morin (1991) ons bring met sy ontwikkeling van gedagtes oor ' $n$ ideësfeer of noösfeer en dat daar ' $n$ noölogie nodig is vir die hantering, waardering, ontginning, en invensie van idees, is aangeleenthede waarsonder samelewings en individue in doodloopstrate beland. Met sy aksent op die nous (gees) bring Morin die lewe van die gees na vore, teenoor die meganisering, industrialisering en instrumentalisering wat ons lewens en instellinge oorgeneem het. Pierre Lévy (1994:231-240) skaar hom heelhartig en welgeartikuleerd met sy klem op die noëtiese by hierdie gedagtes van Morin.

3 Die herontdekking van taal, teenoor die erodering daarvan, moet geproklameer word. Kyk maar na die gereelde berigte oor nie soseer eksamenflaters nie, maar oor die flaters in en met eksamenvraestelle om te verstaan hoe taal geminag word. Ons het traak-my-nie-agtig geraak oor taal. Met verwysing na Orwell se 1984 wys Evans (2004:50) daarop

that to lose the meaning of language we also lose our personal and social history; those living in a world without history have no mechanisms for the evaluation of truth and certainty.

En later

Above all else, this world depends upon literacy and an ability to use and understand language (Op.cit. 107).

Nog meer: die nie-materiële van ons menswees, die geestelike krag van sinvolle lewens hou direkte verband met taal. Taalverlies is sinverlies is lewensverlies is toekomsloos. Steiner (2001:5) is eksplisiet hieroor: 
The future tense... looks to be specific to homo sapiens. As does the use of subjunctive and of counter-factual modes which are themselves kindred, as it were, to future tenses. ... It seems to me that this fantastic, formally incommensurable 'grammatology' of verb futures, of subjunctives and optatives, proved indispensable to the survival, to the evolution of the 'language animal'....

Nóg die mark, nóg ekonomiese groei, nóg tegno-wetenskaplike ambisies en prestasies is bevoeg om alleen en op sigself die sin van ons lewens en die toekoms te beredder.

4 In plaas daarvan om toe te laat dat graadsertifikate bloot bewyse van bywoning is, moet betrokkenheid by kennisinhoude in die breedste en volste moontlike sin en by alle verwante literatuur dringend by studente in ere herstel word. Uit hierdie betrokkenheid kan probleemoplossings van ' $n$ algehele nuwe aard van stapel gestuur word, soos later na aanleiding van Deleuze en Guattari se werk aangetoon sal word wat ons weglei van al die skynoplossings verduister deur die aktiwiteite om die skyn te verwesenlik. Die dimensie van eenduidige denke (en die gevolglike miskyk van meervoudige denke), wat meesal oorheers in die wetenskap- en professionele werkgebied van die inligtingkundige en wat ook weerklank vind in informatiseringsprosesse, in die aktiwiteite van kennis- en inligtingbestuur, in kennisorganisasie en in die normale inligtingaktiwiteite, bring ook ' $n$ verskraling in kwaliteit oor ' $n$ wye linie van wetenskap-, navorsing- en onderrigwerk in die algemeen mee. Wat hier gebeur, naamlik die vereenvoudiging van die denke, herinner ' $n$ mens aan die waarskuwing van Heidegger (1971:19) in sy opmerking: "Wat beteken denke? Bewaar ons van die blinde drif wat op hierdie vraag ' $n$ honende antwoord in die vorm van 'n formule gee." (My vertaling). Die kompleksiteit van denke word deur " $n$ spottende blindheid afgetakel tot die enkelvoudigheid van maklik begrypbare en selfs grypbare formules. Heidegger se protesterende versugting is dat ons hiervan (die verlies van 'n goeie begrip van denke!) bewaar moet word. Dit vergelyk goed met Avital Ronel (1989: 2627, 419-420, vn25) se waardevolle bespreking van Heidegger al doen sy dit met ' $n$ ander aksent. Sy parafraseer hierdie sin soos volg:

\section{.. the question of what is called thinking or what does call for thinking must renounce access to an urge, an urge for blindness. This form of blindness would permit us to snatch at a quick answer in the form of a formula' - a quick answer that would be graspable by the right kind of dialing system. All of this must be given up if we are to stay with the question that asks, 'Was heisst denken?' (Ronel 1989:26-27).}

5 Fundamentele kennisontginning en goed opgevoede studente, opgevoed tot volle denkontplooiing, eerder as die fokus op blote funksionele fragmente van kennis en op halfopgeleide studente, is wat ons land en die wêreld dringend nodig het om vrede, voorspoed en geluk te verwesenlik en katastrofes en barbaarsheid te vermy. Die universiteit bly in hierdie verband ' $n$ sentrale instelling. Oudmodies en uitgedien, middeleeus, sal baie wel sê, want binne "n sogenaamde "kennisekonomie" behoort universiteite die Mark en slegs die Mark te help verheerlik. Hierdie eensydigheid kan nie sonder protes gelaat word nie, want dit sal nie straffeloos tot in ewigheid kan voortwoeker nie. Ons almal sal uiteindelik die slagoffers wees.

Om hierdie protesgedagtes saam te vat, maar ook verder te voer, vereis ' $n$ veskuiwing in ons opvatting oor denke. Vir hierdie doel word hier voorgestel dat die term meervoudige denke of ook komposisionele denke gebruik word. 


\section{Meervoudige of komposisionele denke}

Die betekenis van beide hierdie denkmodi behoort gaandeweg duideliker te word. Die werklike voldoening hieraan kan die bogenoemde probleme van die vermoording en versmoring van denke deur allerlei instellings die hoof bied en ons selfs sinvol die toekoms inneem.

Denke in sy veelvoud hou verband met veel meer as ratio en die rasionele, soos dit byvoorbeeld geillustreer word met die gedagte van refleksie of besinning van Heidegger (1983), met verbeelding wat deur soveel denkers beklemtoon word, onder andere Bachelard (1968), met fantasie van Deleuze en Foucault (1980:169) saam met hom en ook Gadamer (1977:12) en dit hou veral weer verband met idees. Hierdie terme kan almal saamgevoeg word in die een term nous (of gees). Edgar Morin (1991) se noösfeer en noölogie skets die ruimte hiervoor.

Om uitdrukking aan hierdie meervoudigheid te gee, gebruik Edgar Morin 'komplekse denke', Badiou 'oneindige denke', Nancy 'eindige denke' en Serres die term 'verbandleggende intellectio', maar om wat dan met die verskillende benoemings te sê?? Miskien juis om die soeke na meervoudigheid te beklemtoon, om presies uit te kom by die filosofiese vermoë om verbande te soek en te lê, oorskrydings van grense te pleeg, en iets nuuts te inventeer. Let ook op Deleuze (1988:83-84) se gedagte van "die denke van die buitekant" in sy boekie oor Foucault waarin hy die meervoudigheid sterk beklemtoon, veral waar hy na Foucault se filosofie as ' $n$ "pragmatiek van die meervoudigheid" verwys.

Waar kom 'n mens uit met die gepraat oor meervoudige denke?

Dit is allereers ' $n$ denke wat in voeling is met die syn of die werklikheid in die meervoudigheid daarvan, met dit wat is in die volheid daarvan, om daarop te antwoord deur ons wyse van dink, ons lewenswyse, ons wyse van verhoudinge te voer en ons wyse van kennis te beoefen. Synsongevoeligheid, of on-syn-igheid, ongevoeligheid vir alles wat is, onvergenoegdheid met dit wat is, afsydigheid van dit wat is, die toppunt van on-sin-nigheid of nihilisme (die verabsolutering van óf sinloosheid of letterlik niksheid), is ons voorland in die afwesigheid van meervoudige denke. Stiegler (2001) verwys hierna as "die siekte van ons tyd".

In sy Syn as gebeurtenis het Badiou (2007) mooi geskets hoe onmoontlik dit is om die syn in enkelvoudige terme en in ' $n$ eenduidige sin te bedink. Kyk veral na die eerste deel van hierdie boek (Badiou 2007:23-120): "Being: multiple and void" vir sy bespreking oor meervoudigheid en hoe denke daarop moet respondeer, alhoewel die res van die boek deurspek is met besinninge oor die meervoudige, byvoorbeeld 'natuurlike meervoudighede' in hoofstuk 12 en 14; 'die vormmeervoudige van intervensie' in hoofstuk 22; 'die natuurlike kwantitatiewe korrelaat van ' $\mathrm{n}$ meervoudige' in hoofstuk 26, om slegs enkele spesifieke voorbeelde te noem. Hy het die gedagte van meervoudigheid in ' $n$ onlangse publikasie weer opnuut treffend uiteengesit (Badiou 2009:5375).

Synsbetrokkenheid is ' $n$ meervoudige betrokkenheid wat op ' $n$ veelvoud van vlakke manifesteer en ontmoet word. Deleuze en Guattari (1987) se Duisend plateaus en Michel Serres (1982) se Genesis (wording of aanvange), wat aan meervoudigheid gewy is, ondersteun hierdie gedagte heelhartig. Om net vir 'n oomblik by Serres stil te staan. Aandag aan almal sou baie tyd vra. ' $n$ Nuwe tema of objek word deur Serres vir die filosofie voorgestel: meervoudigheid. Hierdie "nuwe objek" vir die filsofie is isomorf aan die nuwe geometrie van die wiskundige Benoit 
Mandelbrot. Fraktale geometrie konstrueer modelle wat vorme wat in die natuur voorkom simuleer, maar vorme wat so kompleks is dat die Euklidiese geometrie dit nie toereikend kan voorstel (representeer) nie. Meervoudigheid is die metaforiese voertuig wat Serres kies om hierdie fraktale, ook die chaotiese en die stochastiese, of onvoorspelbare, voor te stel. Die objek van die boek is nuut maar ook bekend.

\section{Oral ken ons dit; oral wil die rede dit ignoreer (Serres 1982:20)... Om meervoudigheid vir enkelvoudigheid te verlaat, verlaat die rede 'n prooi vir'n skaduwee. (Op. cit. :17).}

Ons is so min verseker van die meervoudige as van die Een.

Ons veronderstel altyd dat ons nie weet nie of dat ons alles weet, ja of nee. Nou, ons weet gemeenskaplik 'n bietjie, middelmatiglik, genoeg, baie, dit fluktueer op verskeidenheid maniere, selfs in die duursaamste en mees gevorderde wetenskappe. Ons bevind ons voor of binne die meervoudigheid, vir meer as driekwart van ons kennis en ons handelinge. ... Meervoudigheid as sodanig, rof gelaat, op skaars maniere verenig, is nie 'n epistemologiese monster nie, maar dit is inteendeel die gewone van situasies, verstaan as situasies van die gewone wetenskaplike, die gebruiklike kennis, die alledaagse werk, kortliks, ons gemeenskaplike objek. (Serres 1982:19-20)... Meervoudigheid word gedink, miskien, maar nooit werklik verstaan nie."(Op. cit. :23). (Die aanhalings uit Serres is my vertalings).

Die meervoudigheid wat so voorgestel word as 'n diskursiewe model moet bevry word van die fenomenologiese, positivistiese, empiristiese bande indien ons by ' $\mathrm{n}$ nuwe epistemologie wil uitkom wat nie langer deel vorm van gewelddadige uitsluitinge nie. Ons moet sover moontlik alles in ag neem. Serres stel voor dat die tradisioneel aanvaarde metodologieë afgewys moet word indien ons by hierdie "nuwe objek" wil uitkom waarmee 'n nuwe filosofie [van meervoudigheid] haar wil bemoei. Die nuwe metode, teenoor die rasionele, binêr-logiese denke, is die meervoudige denke wat spelend binne die meervoudige geheel van dit wat is heen en weer beweeg. Dit is presies ook die boodskap van Mandelbrot (1983:19):

\section{Some quantity that is commonly expected to be positive and finite turns out to be infinite or to vanish... Such misbehaviour looks most bizarre and even terrifying [to a scientist] but a careful re-examination shows it to be quite acceptable ... as long as one is willing to use new methods of thought.}

Ons sien in ons politiek van die dag, die ekonomie van die dag, die opvoedkunde van die dag, die wetenskap van die dag, selfs die regspleging van die dag, ondanks al die vrugtelose gehamer op inheemse kennis, steeds die gevangenskap binne hierdie lineêre, representerende denke wat altyd direk of by implikasie moet uitloop op geweld en die regverdiging van geweld - ook institusionele geweld - sensuur, skorsings, insluiting en uitsluiting, ensovoorts.

In die lig van hierdie nuwe metode, die meervoudige denke, komposisionele, a-kritiese denke, lyk die hele veld van probleemdenke aansienlik anders. Enkele opmerkinge van Deleuze en Guattari, as van die belangrikste eksponente van meervoudigheid, sal hier gepas wees en miskien ook aandui waarom daar so min 'sukses' op hierdie terrein te bespeur is. ' $n$ Besonder gepaste vertrekpunt vir ' $n$ begrip van hulle siening kan verwys word na die inleiding tot die boek Duisend plateaus (1987) onder die titel "risoom". Vir hulle is dit nie moontlik om die meervoudige werklikheid in enkelvoudige terme te bedink nie. Die denke moet ook meervoudig wees en so ook taal as die belangrike voertuig van denke. Taal is heterogeen en sodra dit ingeperk word (en 'n mens kan byvoeg: vir doeleindes van inperking en uitsluiting gebruik (misbruik) word), word taal gesteriliseer en raak dit impotent, dus geheel en al onbevoeg om uitdrukking aan hierdie 
werklikheid te gee. Om soepel en meervoudig te wees en ooreenkomstig die heterogeniteit van taal te dink moet die denke nie inspirasie vind in waarheid en dogma nie, maar in waardes en lewe. Volgens die dogmatiese beeld van die denke vind die denke ankers in die simboliek van die boom - 'n arboretiese werklikheid. Hiervolgens verloop die denke lineêr en ordelik. Hierteenoor, ten einde getrou te wees aan die meervoudigheid, kies Deleuze en Guattari die beeld van die risoom. Hiervolgens maak die denke nimmereindigende en altyd nuwe konneksies of verbindinge en ook verbintenisse. Dit kom veel nader aan chaos as aan orde. Alle werklikheidsaspekte word deurentyd oor en weer aan mekaar verbind: materieel, sosiaal, kultureel, intellektueel. Dit skep nuwe perspektiewe op die sosio-politiek (die polis en die socius) en op die toekoms.

Probleme is nie doodgewone entiteite nie, maar meervoudighede of komplekse van verhoudinge en oorenstemmende singulariteite. Daarom moet die ondersoek na probleme altyd binne ' $n$ gemeenskap geskied. Elke oplossing moet gegrond wees in die omstandighede van die probleem. Daarom is dit nodig om 'die gekleurde digtheid van die probleem' binne te dring. Probleme en hulle simboliese velde staan in ' $n$ verhouding tot tekens en die meervoudige denke is al benadering wat hier regtig kan geld. In die meeste gevalle van probleemoplossing bly mense egter gevange in die dogmatiese beeld van die denke wat die waarheid van probleme verwys na die moontlikheid van oplossings. Rasionalistiese, soos empiristiese en positivistiese metodes vir oplossings vir veronderstelde probleme berus op die berekening van probleme, vrae en oplossings en nie op metodes van invensie wat gepas is vir gekonstitueerde probleme en werklike begrype van vrae nie, soos dit ingebed is in die komplekse netwerke van sake en verhoudinge.

Groot denkopofferinge is gemaak en denkers wat ingesien het hoe belangrik hierdie gedagtes vir ons verstaan van en omgang met die werklikheid is, is aan baie verguising blootgestel. En tog het hulle werk deurbrake op alle vakgebiede meegebring. Die hartseerste saak is om te aanskou hoe meer en meer mense, denkers, hulle rug op hierdie "bevryding tot meervoudige denke" draai en terugkeer tot die armoede van lineêre, eenduidige denke. Hierteen moet hewig wal gegooi word. Stengers (2009) is een voorbeeld van iemand wat met mening en met sterk argumente walgooi. So ook Salomon (2006) met sy studie oor wat hy "die hoë-risiko beskawing” noem.

Representasie is die sleutelwoord, maar is ook in meer as een geval die gevaarlike woord. Michel Serres is eksplisiet wanneer hy praat van "die vloek van representasie". Alles word hierdeur en hiermee ingeperk, vasgevang en opgesluit. Representasie beklemtoon dit wat teenwoordig is, hier voor my is, direk gekonfronteer kan word. Sake wat so by my uitkom kan maklik die besef laat ontstaan dat dit al is wat daar is. Buite hierdie sake wat so by my uitkom, lê nog baie ander dinge, selfs belangriker dinge, dinge wat veel meer bepalend van menslike lewe en sin is.

Om hierdie rede het ' $\mathrm{n}$ groot groep belangrike denkers duidelik onderskei tussen hierdie twee werklikheidsaspekte: dit wat direk toeganklik is en maklik meetbaar en dit wat moeilik toeganklik is en haas onmeetbaar bly. Menslike kennis van die werklikheid en denke oor die werklikheid moet dus hiermee rekening hou. Meesal gebeur dit nie en daarom kry ons met soveel distorsies te doen in sowel teorie as praktyk. Die grootste rede hiervoor is dat 'n enkele denkmodus wat heeltemal ontoereikend is hiervoor gebruik word. Dit versteur die werklikheid en uiteindelik ook ons lewens. In menslike praktyke word daar dikwels gewerk asof die aarde eintlik maar plat is terwyl ons tog al so lank weet dat dit rond is. Dit maak al die verskil.

Om hierdie twee dimensies te aanvaar en daarmee te werk sonder om die een tot die ander te herlei of veral te reduseer, is noodsaaklik. Hierdie meerdimensionele opvatting van die 
werklikheid vra terselfdertyd ook ' $n$ meerdimensionele denkbenadering. Wie dit weier, dink op 'n ontoereikende wyse. Gelukkig word ons hierin baie gehelp deur verskeie denkers/wetenskaplikes wat duidelik tussen die twee werklikheidsdimensies onderskei en ander wat ewe duidelik tussen die twee verskillende denkmodi onderskei. Elk van hierdie onderskeidinge word boonop meesal op verskillende maniere benoem. Daar bestaan dus ' $\mathrm{n}$ ryk verskeidenheid terme vir beide die dimensies en die modi.

So word daar tussen die meetbare en die onmeetlike onderskei wat albei natuurlik ewe werklik is (Bernardis \& Hagene), tussen die berekenbare en die onvoorsienbare (Ekeland), kristal en rook (Atlan), noodsaaklikheid en toeval (Monod), determinisme en indeterminisme (Prigogine en Stengers), reël en paradoks (Lyotard), die reëlmatige en die tabulêre (Serres), boom en risoom (Deleuze en Guattari). Vanselfsprekend behoort die denke hiermee in pas te wees anders sal verskraling en verarming (sommige gebruik sterker terme soos katastrofe en barbaarsheid) ons voorland wees, wat tans die geval is soos reeds aangetoon is.

Voorbeelde van toereikende denke is byvoorbeeld die onderskeid wat die filosoof Heidegger gemaak het tussen voorstellende denke en mediterende denke. Blaise Pascal het al enkele eeue gelede onderskei tussen l'esprit de géométrie en l'esprit de finesse. Ander gebruik terme soos calculus en aesthesis (Wersig), aggressiewe en spekulatiewe intellek (Hans Jonas), grammatika en retoriek (Jacques Lacan) om dieselfde onderskeid te beklemtoon. Michel Serres gebruik slegs een term verbandleggende intellectio om hierdie omvangryke menslike denkvernuftigheid te versinnebeeld wat noodwendige tot invensies moet lei en wat terselfdertyd die impotensie (vermoording en versmoring) van denke en taal waartoe alle eensydighede en reduksies onvermydelik lei, moet en kan troef.

Die standaard of selfs gestandaardiseerde, of 'natuurlike' antwoord (omdat almal dink dit is die voordiehandliggende en vanselfsprekende) van die lineêre, representatiewe denke is die toepassing van ' $n$ binêre logika waardeur die begrippepare teen mekaar afgespeel word ten gunste van een van die twee, gewoonlik die eerste. Die res van die terme sowel as die dimensie van die werkliheid waarna dit verwys gaan gewoonweg verlore of is nie relevant nie, of, selfs nie bekostigbaar nie. Hiermee word die pad na die afgronde voorberei.

Hierteenoor is die rykdom van die twee stelle begrippe veral geleë in die oneindige aantal moontlike kombinasies van terme waardeur daar elke keer iets anders en nuuts aan werklikheid verskyn. Hiervoor word 'n ander soort logika as die rigiede binêre logika benodig - 'n soort donserige of pluiserige logika (" $n$ soort vloeibare, beweeglike logika volgens die bioloog, Atlan (1979), wat 'n mens miskien selfs ' $n$ vlugvoetige logika kan noem, wat daartoe in staat is om die lewende (anders as minerale) te artikuleer. In die lig van die werk van Deleuze en Guattari sou 'n mens van "n "risomatiese logika" kon praat. Guattari (1989) stel wat hy noem "n "ekosofiese logika" voor deur middel waarvan die drie heterogene ekologiese domeine wat hy onderskei: die omgewing, die sosiale en menslike subjektiwiteit, op komposisionele wyse en in wysheid met mekaar verbind en selfs geïntegreer kan word. In sy poging om "die eer van die denke te red" wys Gasché (2007:296), ter bevestiging van die voorafgaande, op die volgende:

What is required of any thinking that tries to save the honor of thinking ... is not the theoretical elaboration of rules ... but a praxis... Rather than proceeding according to established rules, thinking is properly thinking only in the absence of preestablished rules. Its fate, therefore, is necessarily linked to ... the task of phrasing what cannot be said.

Aangesien elk van die genoemde verskillende terme iets spesiaal en eiesoortig beklemtoon, moet behoorlike erkenning aan elk verleen word eerder as dat ons gedwing word om tussen sekeres ten 
koste van die ander te kies. Daar kan selfs heelwat meer terme wees, of daar is inderdaad heelwat meer, as wat hier gelys is. Hierdie terme spel allereers die ryk meervoudigheid van die werklikheid uit. Terselfdertyd gee dit uitdrukking aan die noëties-poëtiese genialiteit van menslike denkvernuf wanneer hierdie vernuf na behore gekultiveer is. Die twee denkterme wat iets van hierdie meervoudigheid beklemtoon, is meervoudige denke en/of komposisionele denke. Die spel van netwerkskepping en verbandlegging tussen die verskillende terme wat telkens in nuwe kombinasies "gekomponeer" word en dus nuwe werklikheidsfasette en -nuanses blootlê, kan ' $n$ noemenswaardige bydrae lewer tot sosiale, politieke en kulturele bankrotskappe van allerlei aard, om nie eers van die uitwissing van indiwiduele ellendes te praat nie. Wat nuut raakgesien word, is dit wat gewoonlik hoop bring en toekomsmoontlikhede ontsluit en sigbaar maak. Hiervoor is ' $n$ goedontwikkelde komposisionele denke nodig. Instellings moet eerder hierop fokus. Wanneer die denke egter versmoor en vermoor word - impotent raak - bly daar min hoopvol oor om raak te sien en voor te lewe.

\section{Bibliografie}

Atlan, H. 1979. Entre le crystal et la fumée: essai sur l'organisation du vivant. Paris: Seuil.

Bachelard, G. 1968. The poetics of reverie: childhood, language and the cosmos. Boston: Beacon Press.

Badiou, A. 2007. Being as event. New York: Continuum.

Badiou, A. 2004. Infinite thought. New York: Continuum.

Badiou, A. 2009. Seconde manifeste pour la philosophie. Paris: Fayard.

Bernardis, M-A. \& Hagene, B. 1995. Mesure et démesure. Paris: Les Éditions de la Cité des Sciences et de l'Industrie.

Butler, J. 2006. Precarious life: the powers of mourning and violence. London: Verso.

Deleuze, G. 1983. Nietzsche and philosophy. New York: Columbia University Press.

Deleuze, G. 1988. Foucault. Minneapolis: University of Minnesota Press.

Deleuze, G. \& Guattari, F. 1987. A thousand plateaus. London: Athlone Press.

Evans, M. 2004. Killing thinking: the death of the universities. London: Continuum.

Foucault, M. 1980. Language, counter-memory, practice. Ithaca: Cornell University Press.

Furedi, F. 2006. Where have all the intellectuals gone? (Second edition). London: Continuum Press.

Gadamer, H-G. 1977. Philosophical hermeneutics. Berkeley: University of California Press.

Gasché, R. 2007. The honor of thinking: critique, theory, philosophy. Stanford: Stanford University Press.

Gumede, W. \& Dikeni, L. 2009. The poverty of ideas: South African democracy and the retreat of intellectuals. Johannesburg: Jacana Media.

Heidegger, M. 1971. Was heisst Denken? Tübingen: Max Niemeyer Verlag.

Heidegger, M. 1983. De tijd van het wereldbeeld. Tielt: Lannoo. 
Lamont, M 2009. How professors think: inside the curious world of academic judgement. Cambridge, Mass.: Harvard Uni9versity Press.

Lévy, P. 1994. L'Intelligence collective: pour une anthropologie du cyberspace. Paris: La Découverte

Mandelbrot, B. 1983. The fractal geometry of nature. New York: W.H. Freeman and Co.

Morin, E. 1990. Introduction à la pensée complexe. Paris: ESF Editeur.

Morin, E. 1991. La méthode: 4. Les Idées: leur habitat, leur vie, leurs moeurs, leur organisation. Paris: Seuil.

Nancy, J.L.2003. A Finite thinking. Stanford: Stanford University Press.

Pascal, B. 1963. Gedachten. Utrecht: Erven J. Bijleveld

Prigogine, I. \& Stengers, I. 1989. Tussen tijd en eeuwigheid: de nieuwe plaats van de mens in de natuurwetenschap. Amsterdam: Uigeverij Bert Bakker.

Ronel, A. 1989. The telephone book: technology, schizophrenia, electric speech. Lincoln: University of Nebraska Press.

Ronel, A. 2003. Stupidity. Urbana: University of Illinois Press.

Salomon, J.J. 2006. Une civilisation à hauts risques. Paris: Éditions Charles Léopold Mayer.

Serres, M. 1995. Genesis. Ann Arbor: Michigan University Press.

Serres, M. 1997. The troubadour of knowledge. Ann Arbor: The University of Michigan Press.

Steiner, G. 1999. Barbarie de l'ignorance. La Tour de l'Aigues: Éditions de l'Aube.

Stengers, I. 2009. Au temps des catastrophes: résister à la barbarie qui vient. Paris: La Découverte.

Stiegler, B. 2001. La technique et le temps 3. Le temps du cinéma et la question du mal-être. Paris: Galilée.

\section{English summary:}

\section{Multiple thinking: Do institutions smother/kill thought?}

Thought is the most distinct ability of humans. For humans to be fully developed beings the full development of this ability is required. If this ability is neglected humans become less human and their relationships are damaged. This damage can, with time, reach alarming proportions. It can cause the collapse of societies and even the downfall of civilisations. No wonder many thinkers through the ages have warned against the fatal consequences of the absence of thought in the full sense of the word. For this reason, the aim should always be the development of our humanity to its fullest and that includes the ability to think. The self-evident implication of this is a fulfilled humanity. This is unfortunately not at all self-evident. The fact that all humans think, does not mean that this capacity has been fully and comprehensively developed in every human being.

This article reflects on the importance of multiple or compositional thinking as the ideal mode of thinking that calls for attention and devotion. It also reflects on the essential problem that 
thought development is very often hindered in individuals and in institutional contexts because of the chosen emphasis on and promotion of thinking in a simplified form. Furthermore, it is a reflection on the possible impoverishing consequences for individuals and societies of such simplifying strategies as it finds expression and comes to fruition in institutional contexts: education, politics, culture, and even religion. Eventually it becomes the general attitude ruling in society as a whole.

The alarming proportions already assumed due to the loss of thorough thinking are immense. It affects schools, universities, scientific work, political institutions, individual life, and administrative activities over a broad spectrum - as a matter of fact, it already affects the whole of society: acts of reading become stereotyped, writing endeavours are limiting rather than enriching factors, cultural contents and dispositions become lean, scientific explorations are often impoverished and fragmented, knowledge becomes a commodity and therefore empty. These are some of the crucial issues affected negatively to the extreme. Efforts to remedy the problems related to these negative effects are cosmetic most of the time. This poses enormous challenges. In case this consideration is valid, as many would suggest, it needs urgent reversal. Some proposals to this effect are made.

\section{The smothering/killing of thinking}

Firstly, we need to reflect on the limitations of limited thought and its consequences. A core question is whether institutions smother and kill multiple thinking in line with the thoughts developed by Mary Evans (2004) in her book: Killing thinking: the death of the universities, and Frank Furedi (2008) in his book: Where have all the intellectuals gone? Intellectual vitality and creativity are to be replaced by, or at least dictated and directed by auditing, assessing, measuring and regulating activities and strategies. Universities are no longer places where the values of independent thought and scholarly and critical activities are highly regarded but have become places where the values of the market place and the economy (of a certain kind) are cultivated and embraced. In this context the skills required for technical and economic competence are not the same as those required for intellectual understanding and an inventive spirit. The 'waste of human lives', implied by this new institutional dispensation, is certainly the most painful experience of all.

\section{Protest thinking}

If this is the case it becomes an urgent matter that the attitudes towards poor thinking should be changed; that the poverty this causes be accepted; and that alternative routes be explored and made available. What is needed is a concerted effort to protest against these mutilating developments. Isabelle Stengers alerts us to the fearful possibility of the time of catastrophes in which we find ourselves and that, in its turn, predicts the advent of a threatening barbarism. It should be realised that the boundaries of academic institutions stretch much further than economic and marketing matters. Universities are there to expand the possibilities of the intellect and this is also highly relevant for any other institution. In addition ideas, and not only practices, that can change and transform the world, should be pursued. Furthermore, the dimensions of language should again be realised and rediscovered. The loss of language means the loss of life which means the loss of a future. It is important to realise that one-sidedness is futile. As Heidegger puts it: Beware of the blind urge that would permit us to snatch at a quick answer in the form of a formula. In the last analysis, what the country needs are students educated towards the full unfolding of thought that will take us away from one-sidedness, from the quick answers caught up in a formula, and its huge potential for grave mistakes, and that will take us forward into a grand future. 


\section{Multiple or compositional thinking}

At the same time an awareness of the complexity of reality, human reality as well as natural reality, in its multiplicity and scope, should be kept vividly alive. Insensitivity to the multiple and the complex nature of being and the real will lead nowhere. No simplified, linear, and hence reductionist, thinking can possibly offer adequate answers to the challenges of such a reality. Only a thought and an institution, willing to accept this and to think accordingly, will have a hope of the fulfilment of meaning and the enrichment of humans and reality. It will open new avenues for thinking about problems. No problem ever exists in isolation. It always emerges in a context with many connections to other situations and problems. A sound understanding of a problem presupposes a sound understanding of contexts and connections within which a problem appears. This requires a different kind, mode, or style of thinking.

We are confronted by two different, but closely interconnected aspects of reality; the one aspect is directly accessible and easily measurable; the other is less accessible and hardly measurable. The acceptance of these two aspects of reality and working with them without reducing the one to the other, while accepting their integration, poses the main challenge. Many thinkers and scientists are aware of this and guide us in this. They are all using their own terminology to articulate the problem. A few examples may help us: the biologist, Henri Atlan, distinguishes between crystal and smoke (or smokiness); the mathematician, Ekeland, distinguishes between the calculable and the unforeseen; Wersig, the information scientist, uses calculable and aesthesis to differentiate the two dimensions; and Monod, another biologist, differentiates between necessity and chance.

Our thinking should be in step with these two dimensions to avoid impoverishment and superficial solutions. There are numerous examples of modes of thinking complying with exactly this. Let us start with Pascal who distinguishes between l'esprit de géométrie and l'esprit de finesse; in the work of the philosopher, Heidegger, we encounter representative and meditative thinking; the social scientist, Hans Jonas, distinguishes between the aggressive intellect and the speculative intellect; Lacan between grammar and rhetoric and Lyotard between rule and paradox. These two modes are not in opposition but complementary and are required as such in order to deal adequately with the corresponding dimensions of the real - the measurable and the immeasurable. When this does not happen we encounter distortions and mutilations in the expressions of knowledge.

At the same time one discovers that the diverse concepts used to articulate the same reality and problem area, together with reflecting on these by various modes of thought, help us towards an infinitely richer and more rewarding way of encountering and giving account of our experiences of the real. And it must be kept in mind that every single term, and there are many more than the examples given here, articulates in a specific, very unique and irreplaceable way aspects of the real. The possibilities of new and different combinations of these conceptual pairs through connective, multiple intellection, are multiple, almost inexhaustible.

Two terms articulate to a great extent precisely this response to the richness of the real, namely the notions multiple or compositional thinking. The game of network creation and the establishment of connectivity that enable the composition of new combinations imply the possibility of engaging in new visions for the future and new hopes to live for. Well developed compositional thinking, instead of impoverished and lean linear thinking, offers almost a guarantee for envisioning new possibilities for the future and significant alternatives to the unworkable and undoable in which societies and individuals are often trapped. 